\title{
Effects of acetorphan, an enkephalinase inhibitor, on experimental and acute diarrhoea
}

\author{
Ph Baumer, E Danquechin Dorval, J Bertrand, J M Vetel, J C Schwartz, J M Lecomte
}

\begin{abstract}
Acetorphan is an orally active inhibitor of enkephalinase (EC 3.4.24.11) with antidiarrhoeal activity in rodents apparently through protection of endogenous enkephalins and a purely antisecretory mechanism. Its antidiarrhoeal activity in man was assessed in an experimental model of cathartic induced secretory diarrhoea as well as in acute diarrhoea of presumed infectious origin. In six healthy volunteers receiving castor oil and pretreated with acetorphan or placebo in a crossover controlled trial, the drug significantly decreased the number and weight of stools passed during 24 hours. About 200 outpatients with severe acute diarrhoea (more than five stools per day) were included in a randomised double blind study of acetorphan against placebo. The significant antidiarrhoeal activity of acetorphan was established using a variety of criteria: (i) the duration of both diarrhoea and treatment were diminished; (ii) no acetorphan treated patient withdrew from the study whereas five dropped out because of worsening in the placebo group; (iii) the frequency of symptoms associated with diarrhoea - for example, abdominal pain or distension, nausea and anorexia - remaining after two weeks was nearly halved; (iv) using visual analogue scales acetorphan treatment was found more effective than placebo by both investigators and patients. There was statistically no significant difference between acetorphan and placebo in respect of side effects, particularly constipation, which often accompanies the antidiarrhoeal activity of $m u$ opioid receptor agonists this difference is attributable to the lack of antipropulsive activity of acetorphan in man. The efficacy and tolerance of acetorphan suggest that enkephalinase inhibition may represent a novel therapeutic approach for the symptomatic management of acute secretory diarrhoea without impairing intestinal transit.
\end{abstract}

It is generally admitted that acute infectious diarrhoea is accompanied with an abnormality of intestinal water and electrolyte transport. ${ }^{1-4}$ As a consequence rehydration with replacement of electrolytes are accepted as the most important therapeutic measures. Antimicrobial agents are also of value in diarrhoea caused by identified intestinal protozoa but are essentially ineffective in the treatment of viral enteric infections which constitute most cases of acute diarrhoea. ${ }^{2+5}$ In addition, $m u$ opiate receptor agonists such as opium derived preparations, diphenoxylate or loperamide are widely used to shorten the duration of the disease, relieve a variety of syrnptoms and reduce the discomfort. Their beneficial effect, however, has become a matter of controversy in view of their limited efficacy and potential side effects. These drugs disrupt forward propulsive motility, increase capacitance of the gut and delay passage of fluid through the intestine allowing, in turn, more time for net absorption of water and electrolytes to occur. ${ }^{68}$ The fact that their antidiarrhoeal activity is always associated with an antimotility effect is probably responsible for some of the major gastrointestinal side effects - that is, pooling of fluid in the distended bowel lumen and enhancement of bacterial colonisation..$^{8-13}$ This has led to the idea that antidiarrhoeal drugs with a purely mucosal antisecretory activity, should lead to a therapeutic improvement. ${ }^{3}$ Two main strategies were used to reach this aim: design weak $\alpha_{2}$ adrenergic receptor blocks devoid of cardiovascular effects ${ }^{1+15}$ and enkephalin like pentapeptides $^{16-18}$ but, so far, the resulting investigational drugs have not gained therapeutic application.

Another strategy was recently suggested by the observations that inhibition of enkephalinase (membrane metalloendopeptidase, EC 3.4.24.11) delays the inactivation of endogenous enkephalins in the brain which, in turn, results in a series of naloxone reversible biological responses. ${ }^{19-21}$ The peptidase is present all along the gastrointestinal tract $^{2223}$ and its inhibition delays the inactivation of exogenous enkephalins by the guinea pig ileum. ${ }^{2+26}$ Moreover, enkephalinase inhibitors exert potent, naloxone reversible antidiarrhoeal activity in the rodent castor oil induced model of diarrhoea. ${ }^{27}{ }^{28}$ Interestingly, this action was not associated with any detectable antitransit effect, ${ }^{27-30}$ which clearly differentiates this class of compounds from $m u$ opiate receptor agonists. ${ }^{31-36}$

In the present study we have assessed the antidiarrhoeal activity of the enkephalinase inhibitor acetorphan in man in two randomised placebo controlled double blind trials. The first was a crossover trial on six healthy volunteers receiving castor oil, a validated model of experimental 'secretory' diarrhoea in man, ${ }^{16}{ }^{37}$ whereas the second one was a parallel study on two groups of about 100 patients each attending their general practitioners for severe acute diarrhoea of presumed infectious origin.

\section{Methods}

STUDY I: CASTOR OIL INDUCED DIARRHOEA

\section{SUBJECTS}

Six healthy volunteers, three men, three women, aged 21 (3) years, with no reported digestive abnormality, particularly no intestinal transit 
disorder, and not receiving any drug treatment, were selected. Their mean (SEM) body weights were $61.0(3.7) \mathrm{kg}(68$ (4) $\mathrm{kg}$ for men, 54 (3) kg for women). Written informed consent was obtained and the study was approved by the local Ethical Committee.

STUDY DESIGN

The study was a double blind, randomised, placebo controlled crossover study of the prevention by acetorphan of diarrhoea elicited by a fixed dose of castor oil. The study comprised two sessions, performed at one week intervals, during which the subjects received placebo and acetorphan capsules in a randomised order. Neither the subjects nor the clinicians were aware of the nature of treatment.

In the morning of each session, generally after one spontaneous stool, each subject absorbed five capsules and, 45 minutes later, $30 \mathrm{~g}$ castor oil (French Pharmacopoeia). The time and weight of each stool was then determined during the following 24 hours.

The capsules for the placebo session contained $200 \mathrm{mg}$ lactose and were undiscernible from those containing acetorphan for which a dosage close to $10 \mathrm{mg} / \mathrm{kg}$ of body weight was selected. The actual acetorphan dosage received by the subjects was $11 \cdot 1(4 \cdot 2) \mathrm{mg} / \mathrm{kg}$, a dosage eliciting more than $50 \%$ inhibitions of plasma enkephalinase for at least six hours.

All side effects were recorded during the 24 hour experimental period.

\section{STATISTICAL ANALYSIS}

The evaluation criteria were the cumulative weights of stools, the total number of stools during the experimental 24 hour period and the delay between administration of the cathartic and the first stool passage. Data were expressed as means (SEM) and analysed by analysis of variance and Student's $t$ test for matched series, using the PCSM program (Deltasoft). Differences were considered significant at a $5 \%$ probability level.

\section{STUDY II: ACUTE DIARRHOEA}

The study was a double blind, randomised, placebo controlled parallel study.

\section{PATIENTS}

Adult outpatients, aged at least 18 years, living in the Parisian district, were eligible if they attended their physician for acute diarrhoea of presumed infectious origin having started less than five days before. Patients not included were those with chronic or iatrogenic diarrhoea, with dysenteric syndrome characterised by fecal blood loss and those who had been given any new drug treatment within one week of admission. No attempt at identifying the bacterial pathogen was made as fecal cultures performed in similar cases generally lead to negative results in a large majority of cases (over $95 \%$ in ref 38 ). Patients were asked to participate after a full explanation of the aims and methods of the study, and all gave informed consent.

\section{TREATMENT}

Identical capsules containing $100 \mathrm{mg}$ either accetorphan or lactose (placebo) were supplied. Each patient was assigned a sequential study number and corresponding bottle containing 60 capsules. Treatment had been previously randomised using a random number table with groups of four.

Patients were given two capsules at the start of the study and were instructed to take one capsule after each unformed bowel movement. Drug administration was continued until recovery, defined as the disappearance of any unformed stool, or for a maximum of 10 days. The remaining capsules were returned to the investigators and were counted to determine the actual number of capsules ingested. No other new treatment was allowed during the trial, except for paracetamol.

\section{STUDY DESIGN}

The patients were seen twice by clinicians not informed of the nature of treatments: for the first time at inclusion (visit 1) and 10-14 days later (visit 2). For each patient the clinicians had a case report form to complete at visits 1 and 2 . It included a specific questionnaire with a report of clinical examinations. The clinicians remained blind all over the study.

Patients were requested to keep a diary in which the following information was reported: time, number and characters of bowel movements, number of capsules taken, possible adverse affects, and their global evaluation of the treatment using visual analogic scales (from $0=$ no efficacy, to $100=$ excellent efficacy). Patients were asked to bring back the diary and remaining capsules at visit 2 and both were checked by the clinicians.

The duration of diarrhoea was defined as the time from the first dose of the trial drug (visit 1) to resolution of diarrhoea, that is the disappearance of unformed stools.

The tolerance was assessed using the spontaneously described symptoms and the visual analogue scales (from 0 to 100 - that is, from bad to excellent tolerance). For each adverse effect, the duration and the severity grade (mild, moderate or severe) were recorded.

\section{STATISTICAL ANALYSIS}

Data were analysed before disclosure of the randomisation. Qualitative data were compared using $\chi^{2}$ and Fischer tests. Quantitative data were compared using two tailed Student's $t$ test. Duration of diarrhoea was analysed by the actuarial method and the log rank test. Differences were considered significant at a 5\% probability level. Values were expressed as means (SEM).

\section{Results}

STUDY I: CASTOR OIL INDUCED DIARRHOEA

Administration of castor oil during the placebo session was followed by bowel movements resulting in the passage of $3.7(0.3)$ stools over 
TABLE I Effects of acetorphan on castor oil induced diarrhoea

\begin{tabular}{lccc}
\hline & Placebo & Acetorphan & Difference \\
\hline Total stool weight $(\mathrm{g} / 24 \mathrm{~h})$ & $672(76)$ & $426(83)^{\star}$ & $-(37(9)) \%$ \\
Number of stools $(/ 24 \mathrm{~h})$ & $3 \cdot 7(0 \cdot 3)$ & $1 \cdot 8(0 \cdot 2) \dagger$ & $-(49(6)) \%$ \\
First stool delay $(\mathrm{h})$ & $4 \cdot 8(1 \cdot 1)$ & $7 \cdot 0(0 \cdot 9) \mathrm{NS}$ & $+(113(59)) \%$ \\
\hline
\end{tabular}

${ }^{\star} p<0.01 ; \dagger=0.002 ;$ NS: not-significant $(p=0 \cdot 142)$.

the next 24 hours, the first one occurring after $4 \cdot 8(1 \cdot 1)$ hours and the total stool weight being 672 (76) $\mathrm{g}$ (Table I and Fig 1).

Among the six subjects, two had taken acetorphan during the first session and four during the second session of the trial. The effect of the treatment on total stool weights was independent of the order of treatment $(\mathrm{p}=0 \cdot 188)$ and there was no interaction between order and treatment $(\mathrm{p}=0.540)$. There was a significant reduction $(-37 \%)$ of stool weight under the action of acetorphan $(p=0.009)$, all six subjects considered individually having a lower stool weight during the acetorphan session than during the placebo session (Fig 2). In addition the mean number of stools during the trial was reduced by $50 \%(\mathrm{p}<0.002)$ during the acetorphan session as compared with the placebo session. There was also a tendency toward an extended delay $(+113 \%)$ between administration of the cathartic and passage of the first stool but the difference failed to reach significance (Table I).

All subjects reported a feeling of nausea and discomfort during the two sessions which can, therefore, be attributed to the intake of castor oil but no other side effect was reported.

\section{STUDY II: ACUTE DIARRHOEA}

\section{PATIENTS}

Initially, 199 patients from the Parisian area were admitted into the study. They were included by 28 investigators during a six month winter period. There was no exclusion because of erroneous admission. Five patients were excluded: two did not take the treatment and three were not followed up. Filling in of diaries was found correct for the 194 patients who completed the study; particularly the number of capsules taken according to the diary was consistent with number deduced from capsules returned at visit 2 . Among the 194 analysed

Figure 1: Effect of acetorphan on castor oil induced diarrhoea in six healthy volunteers: mean cumulative stool weights. The same subjects received acetorphan or placebo in two separate sessions.

Comparison between the two sessions by analysis of variance and Student's t test for matched series: $p<0.001$.

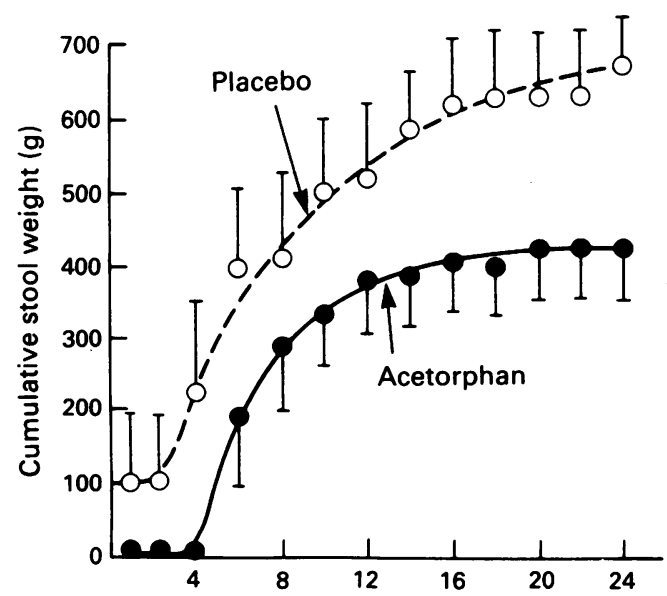

Time after castor oil administration (h)

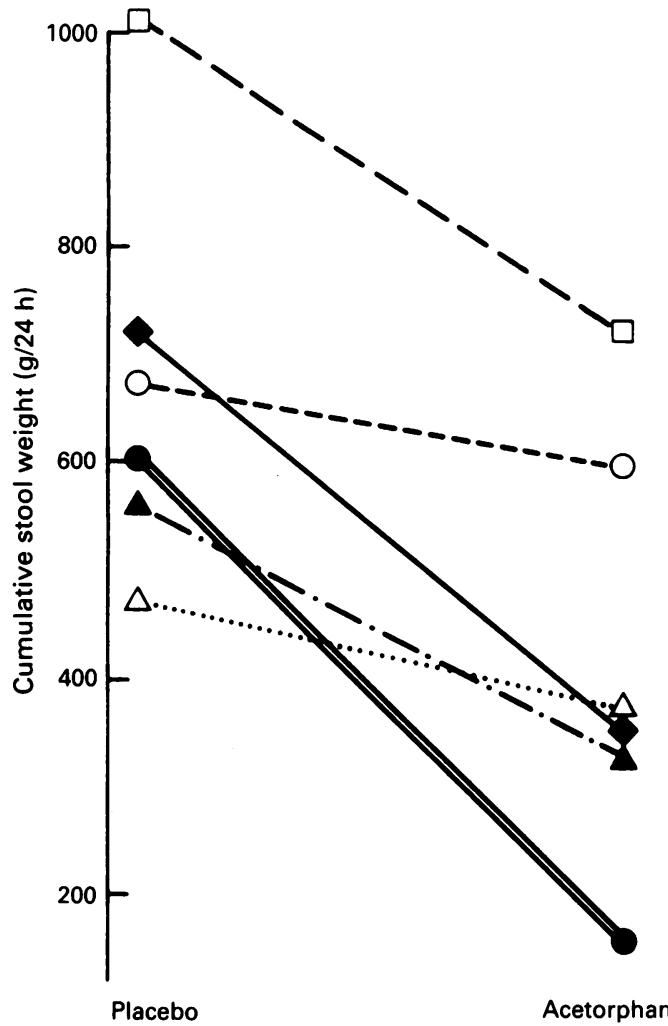

Figure 2: Effect of acetorphan on castor oil induced diarrhoed in six healthy volunteers: individual stool weights $(g / 24 h)$.

patients, 96 received acetorphan and 98 placebo. There were no significant differences in the various characteristics of the groups on admission (Table II).

\section{DURATION OF DIARRHOEA}

Five patients withdrew before the study's completion because of worsening or lack of improvement of diarrhoea; all five patients had received placebo. At visit 2, 30 patients had still unformed stools during the preceding 24 hours: seven in the acetorphan group $(7 \cdot 4 \%)$ and $23(23.5 \%)$ in the placebo group $(p<0.002)$. These 35 patients could not be included in the analysis of the duration of diarrhoea when expressed as mean. The mean duration of diarrhoea was, however, shorter in the acetorphan group, $3 \cdot 4(0 \cdot 1)$ days, than in the placebo group, $4 \cdot 4(0 \cdot 2)$ days $(\mathrm{p}=$

TABLE II Characteristics of the two groups of patients with acute diarrhoea at inclusion

\begin{tabular}{|c|c|c|}
\hline Patients & Acetorphan & Placebo \\
\hline $\begin{array}{l}\text { Included (n) } \\
\text { Excluded/lost from view (n) } \\
\text { Analysed (n) } \\
\text { Age (yr) } \\
\text { (range) } \\
\text { Men (\% of patients) } \\
\text { Weight }(\mathrm{kg})^{\star} \\
\text { Duration of diarrhoea before inclusion } \\
\text { (days) }^{\star} \\
\text { Stools during the preceding } 24 \mathrm{~h}(\mathrm{n})^{\star} \\
\text { Anal burning (\%) } \\
\text { Spontaneous abdominal pain (\%) } \\
\text { Nausea }(\%) \\
\text { Anorexia }(\%) \\
\text { Pain on abdominal palpation }(\%) \\
\text { Abdominal distension }(\%) \\
\text { Fever }(\%)\end{array}$ & $\begin{array}{l}96 \\
0 / 1 \\
95 \\
40 \cdot 2(1 \cdot 7) \\
(19-89) \\
42 \\
65 \cdot 1(1 \cdot 1) \\
1 \cdot 7(0 \cdot 1) \\
5 \cdot 3(0 \cdot 2) \\
50 \\
88 \\
76+ \\
82 \\
85 \\
75 \\
33\end{array}$ & $\begin{array}{l}102 \\
2 / 2 \\
98 \\
38 \cdot 6(1 \cdot 5) \\
(18-84) \\
52 \\
65 \cdot 8(1 \cdot 2) \\
\\
1 \cdot 6(0 \cdot 1) \\
4 \cdot 9(0 \cdot 2) \\
48 \\
90 \\
62 \\
77 \\
85 \\
75 \\
39\end{array}$ \\
\hline
\end{tabular}

*Values given as means (SEM). There was no significan difference between treatment groups in any of the characteristics except $+(p<0.05)$. 
Figure 3: Actuarial curves of diarrhoea in 193 patients with acute diarrhoea treated with acetorphan or placebo. Comparison between the two treatment groups by log rank test: $p<0.001$.

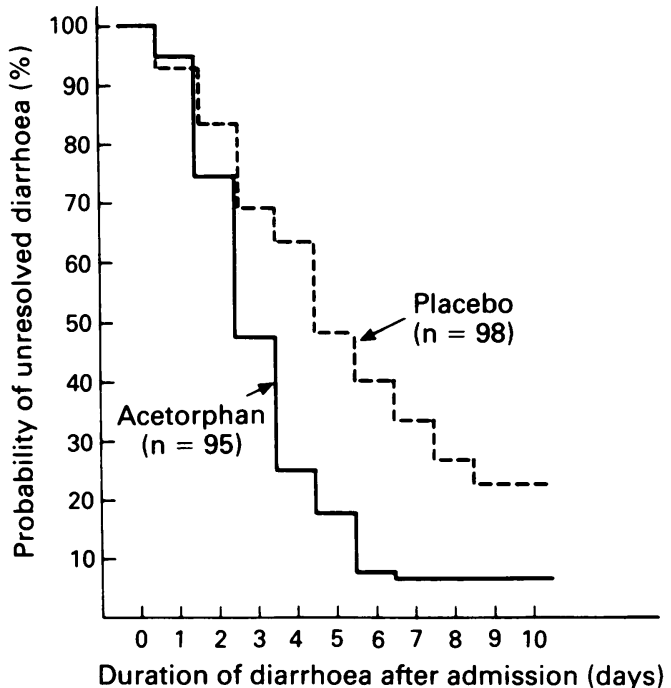

$0.001)$. Using the actuarial approach - that is, determining the probability of unresolved diarrhoea at each day after admission, all the patients were taken into account and their recovery was faster in the acetorphan group than in the placebo group $(\mathrm{p}<0.001)$ (Fig 3). For instance on day 4, the cumulative probabilities of recovery were $75(5) \%$ and $37(5) \%$ in the acetorphan and placebo groups respectively.

\section{OTHER CRITERIA OF EFFICACY}

Functional and physical signs still present on the second visit are shown in Table III. Each of them, except for fever, was significantly more frequent in the placebo group than in the acetorphan group.

The duration of treatment and the total number of capsules taken were significantly less in the acetorphan group than in the placebo group (Table IV).

The evaluations of global therapeutic efficacy by the physicians and the patients, using visual analogue scales, were in good agreement and showed, in both cases, a highly significant superiority of acetorphan over placebo (Table IV).

\section{TOLERANCE}

The frequency and the nature of the spontaneously reported adverse effects were similar in the two treatment groups, particularly constipation was rare in both groups (Table V).

\section{Discussion}

The antidiarrhoeal activity of acetorphan was established here on an experimental model of diarrhoea as well as on acute diarrhoea of presumed infectious origin.

The drug action on the castor oil induced diarrhoea was characterised by significant reductions (by about $40-50 \%$ ) in the number and weight of stools passed during 24 hours; there was also a doubling of the delay for the passage of the first stool but this failed to reach significance (Table I). All these changes were qualitatively similar to those induced by acetorphan (or loperamide) in castor oil treated rodents."7
Because, in these animals, there was a complete inhibition of the antidiarrhoeal effect of enkephalinase inhibitors by naloxone, an opiate receptor blocker, it appears likely that the effect of these agents results from protection of endogenous enkephalins. This protection presumably occurs at the level of peripheral tissues because (i) acetorphan given by oral route is readily hydrolysed into the active inhibitor thiorphan ${ }^{28}$ which does not cross the blood brain barrier $^{1920}$; (ii) in rats enkephalinase inhibitors are devoid of antidiarrhoeal activity when administered intracerebroventricularly and, when administered intraperitoneally, their action is not blocked by intracerebroventricular naloxone. ${ }^{27}$

The diarrhoea induced by castor oil, which appears to result from changes in fluid and electrolyte transport ${ }^{39+0}$ and not from stimulation of gastrointestinal smooth muscle contractility, ${ }^{+1+2}$ seems a valid model of experimental hypersecretory diarrhoea. Accordingly delta

TABLE III Effects of acetorphan in acute diarrhoea: symptoms and clinical signs at the end of the tria

\begin{tabular}{lcl}
\hline Symptoms and signs & $\begin{array}{l}\text { Acetorphan } \\
n(\%)\end{array}$ & $\begin{array}{l}\text { Placebo } \\
n(\%)\end{array}$ \\
\hline Diarrhoea & $7(7 \cdot 4)$ & $23(23 \cdot 5) \dagger$ \\
Anal burning & $3(6 \cdot 3)$ & $11(23 \cdot 9)^{\star}$ \\
Spontaneous abdominal pain & $8(9 \cdot 6)$ & $18(20 \cdot 5)^{\star}$ \\
Nausea & $5(6 \cdot 9)$ & $11(17 \cdot 7)^{\star}$ \\
Anorexia & $16(20 \cdot 3)$ & $27(35 \cdot 5)^{\star}$ \\
Pain on abdominal palpation & $7(8 \cdot 5)$ & $27(32 \cdot 5) \ddagger$ \\
Abdominal distension & $13(18 \cdot 3)$ & $26(34 \cdot 7)^{\star}$ \\
Fever & $0(0)$ & $2(5 \cdot 4) \mathrm{NS}$
\end{tabular}

Data were recorded blindly during the second visit to the physician (10-14 days after inclusion). $n=$ number of patients $\%=n \times 100 /$ number of patients who had this symptom or sign on visit 1 . Comparison between acetorphan and placebo groups using a two tailed Student's $t$ test. ${ }^{\star} \mathrm{p}<0.05 ;+\mathrm{p}<0.01 ; \neq \mathrm{p}<0.001$; NS: not significant.

TABLE IV Comparison of treatments of patients with acute diarrhoea who received acetorphan and placebo

\begin{tabular}{|c|c|c|}
\hline & Acetorphan & Placebo \\
\hline Voluntary interruption of treatment & $0 / 96$ & $5 / 103$ \\
\hline Duration of treatment (days) & $3 \cdot 0(0 \cdot 2)$ & $\cdot 4(0 \cdot 3$ \\
\hline Total number of capsules & $11.6(0.9)$ & $15 \cdot 5(1 \cdot 2)^{\star}$ \\
\hline Probability of recovery on day 4 & $75(5) \%$ & $37(5) \% \dagger$ \\
\hline $\begin{array}{l}\text { Global evaluation of efficacy (analogue } \\
\text { scale from } 0 \text { to 100): }\end{array}$ & & \\
\hline Rating by physicians & $83(2)$ & $61(3) \dagger$ \\
\hline Rating by patients & $82(2)$ & $62(3) \dagger$ \\
\hline
\end{tabular}

Values are means (SEM). Comparison between acetorphan and placebo groups using a two-tailed Student's $t$ test: $\mathrm{p}<0.01 ;$ tp $<0.001$.

TABLE V Clinical tolerance in patients with acute diarrhoea treated with acetorphan and placebo

\begin{tabular}{|c|c|c|}
\hline & Acetorphan & Placebo \\
\hline Number of adverse effects & 35 & \\
\hline Patients with adverse effects $n(\%)$ & $16(16 \cdot 8)$ & $18(18 \cdot 4)$ \\
\hline \multicolumn{3}{|l|}{ Nature of the most frequent effects: } \\
\hline Nausea & 8 & 7 \\
\hline Thirstiness & 6 & 7 \\
\hline Vertigo & 6 & 7 \\
\hline Constipation & 4 & 2 \\
\hline Headache & 2 & 2 \\
\hline \multicolumn{3}{|l|}{ Severity of adverse effects: } \\
\hline Mild & 10 & 15 \\
\hline Moderate & 20 & 17 \\
\hline Severe & 5 & \\
\hline Duration (days) & $2 \cdot 5(0 \cdot 1)$ & $3 \cdot 8(0 \cdot 2)$ \\
\hline \multicolumn{3}{|l|}{ Global evaluation of tolerance } \\
\hline $\begin{array}{l}\text { (analogue scale from } 0 \text { to 100): } \\
\text { Rating by physicians }\end{array}$ & $89(2)$ & $89(1)$ \\
\hline Rating by patients & $93(\tilde{L})$ & $87(2)$ \\
\hline
\end{tabular}

Values are means (SEM). There was no significant difference between treatment groups. 
opioid receptor agonists and enkephalinase inhibitors, both devoid of antimotility effects, were recently found active on this model. In fact a similar mechanism may mediate the final action of both classes of compounds as delta receptor agonists exert antisecretory effects triggered either directly on the intestinal mucosa or indirectly via receptors ${ }^{+3}$ of the submucosal plexus. ${ }^{+17}$ Acetorphan was shown to reduce, in a naloxone reversible manner, the net fluxes of water, $\mathrm{Na}^{+}$and $\mathrm{K}^{+}$in the jejunum of cholera toxin treated $\log ^{48+9}$ as well as to block inflammatory fluid secretion in the cat gall bladder. ${ }^{50}$

The second trial established the activity of acetorphan in acute diarrhoea, as judged from a large variety of criteria. For instance, all five patients who spontaneously withdrew from the study before completion had received placebo. At the end of the trial - that is, after 13-14 days, a significantly higher proportion of patients receiving placebo still had diarrhoea than when treated with acetorphan ( $23 \%$ against $7 \%$, $\mathrm{p}<0.002)$; the duration of treatment and total number of capsules taken were significantly lower in the acetorphan group; the duration of diarrhoea was significantly reduced after acetorphan as judged for instance by the probability of recovery on day $4(75 \%$ against $37 \%, \mathrm{p}<0.001)$; at the end of study the frequency of clinical signs traditionally associated with diarrhoea either spontaneously reported by the patient - for example, sensation of anal burning, nausea, anorexia - or recorded by the investigator - for example, pain on abdominal palpation or abdominal distension - was about two-fold higher in the placebo group; finally both the investigators and patients found the acetorphan treatment significantly $(\mathrm{p}<0.001)$ more effective than treatment with placebo.

Although all these criteria unambiguously establish the antidiarrhoeal efficacy of a new therapeutic class, the possible benefit expected from its use has to be carefully weighed: acute diarrhoea is considered, in most cases, as a self limiting disease and the use of drugs such as $m u$ opiate receptor agonists is often regarded as unnecessary and potentially unsafe. Nevertheless, it should be underlined that, in a population of rather severely affected patients, like the one studied here (as shown by the mean number of stools at inclusion - that is, more than five per day), about $25 \%$ of the subjects receiving placebo had still diarrhoea and associated symptoms about two weeks after the start of the disease. The discomfort of patients and social cost associated with such a persistence of the disease state should be taken into account.

As far as side effects are concerned, enkephalinase inhibitors appear to be devoid of the major ones associated with the use of antidiarrhoeal $m u$ opiate receptor agonists. Even when crossing the 'blood-brain barrier' (which is not the case for acetorphan given orally), these compounds do not depress the respiratory centres in the central nervous system and are devoid of dependence induction liability. ${ }^{28} 2951$ In addition the central nervous system side effects, such as dizziness or irritability, reported with $m u$ receptor agonists, even those purported to enter the brain with difficulty, ${ }^{8}$ were not detected here. The lack of antimotility effects of acetorphan in rodents ${ }^{27} 28$ and healthy volunteers ${ }^{52}$ was confirmed in the present trial by the fact that the occurrence of constipation did not significantly differ in the two groups. Constipation is consistently induced by $m u$ receptor agonists. ${ }^{534}$ In agreement, in a double blind randomised trial against loperamide in acute diarrhoea, acetorphan was found at least as effective as the $m u$ receptor agonist as an antidiarrhoeal agent but to induce significantly less reactive constipation (Roge, Baumer, Berard, Schwartz and Lecomte, submitted). From these differences, it can be reasonably expected that side effects associated with antimotility drugs for example, facilitation of bacterial colonisation, invasion by Shigella, extension of the period of excretion of bacterial pathogens and precipitation of ileus and bowel dilatation ('toxic megacolon') $)^{11}$ should not occur with enkephalinase inhibitors.

1 Powell DW. Muscle or mucosa: the site of action of antidiarrheal opiates? Gastroenterology 1981; 80: 406-8.

2 rheal oplates? Gastroenterology $1981,80: 406-8$. of acute diarrhea. Am 7 Med 1985; 78: 81-90.

3 Edelman R. Prevention and treatment of infectious diarrhea. Speculations on the next 10 years. Am F Med 1985; 78: 99106.

4 Binder HJ, Sandle GI. Electrolyte absorption secretion in the mammalian colon. In: Johnson LR, ed. Physiology of the gastrointestinal tract. 2nd ed. New York: Raven Press, 1987: 1389-418.

5 Bradshaw MJ, Harvey RF. Antidiarrheal agents: clinical pharmacology and therapeutic use. Med Prog 1983; 10: 5565 .

6 Schiller LR, Davis GR, Santa Ana CA, Morawski SG, Fordtran JS. Studies on the mechanism of the antidiarrheal Fordtran JS. Studies on the mechanism of the antidian

7 Schiller LR, Santa Ana CA, Morawski SG, Fordtran JS. Mechanism of the antidiarrheal effect of loperamide. Gastroenterology 1984; 86: 1475-80.

8 Ruppin H. Review: loperamide - a potent antidiarrheal drug with actions along the alimentary tract. Aliment Pharmacol Therap 1987; 1: 179-90.

9 Garret JM, Saver WG, Moertel CG. Colonic motility in ulcerative colitis after opiate administration. Gastroenterology 1967; 53: 93-100.

10 Dupont HL, Hornick RB. Adverse effect of lomotil therapy in Shigellosis. FAMA 1973; 226: 1525-8.

11 Brown JW. Toxic megacolon associated with loperamide therapy. $\mathcal{F} A M A$ 1979; 241: 501-2.

12 Marcovitch H. Loperamide in 'toddler diarrhea'. Lancet 1980; i: 1413 .

13 Novak E, Lee JG, Seckman CE, Phillips JP, Di Santo AR. Unfavourable effect of atropine-diphenoxylate (Lomotil) therapy in lincomycin-caused diarrhea. $\mathcal{F} A M A 1976 ; 235$ : $1451-4$.

14 McArthur KE, Anderson DS, Durbin TE, Orloff MJ, Dharmsathaphorn K. Clonidine and lidamidine to inhibit watery diarrhea in a patient with lung cancer. Ann Intern Med 1982; 96: 323-5.

15 Sninksy CA, Davis RH, Clench MH, Thomas KD, Mathias JR. Effect of lidamidine hydrochloride and loperamide on gastric emptying and transit of the small intestine. Gastroenterology 1986; 90: 68-73.

16 Ryan J, Leighton J, Kirksey D, McMahon G. Evaluation of an enkephalin analog in man with castor oil-induced diarrhea. Clin Pharmacol Ther 1986; 39: 40-2

17 Berschneider HM, Martens H, Powell DW. Effect of BW 942 $\mathrm{C}$, an enkephalin like pentapeptide, on sodium and chloride transport in the rabbit ileum. Gastroenterology 1988; 94: 12736

18 Shook JC, Lemcke PK, Gehrig CA, Hruby VJ, Burks TF. Antidiarrheal properties of supraspinal Mu and Delta and

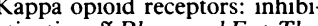
tion of diarrhea without constipation. F Pharmacol Exp Ther
1989; 249: 83-90.

19 Schwartz JC, Costentin J, Lecomte JM. Pharmacology of enkephalinase inhibitors. Trends Pharmacol Sci 1985; 6: $472-6$.

20 Schwartz JC. Enkephalinase inhibitors as drugs. In: Sandler M, Smith HJ, eds. Design of enzyme inhibitors as drugs. New York: Oxford University Press, 1989: 206-20.

21 McKelvy JF, Blumberg J. Inactivation and metabolism of neuropeptides. Ann Rev Neurosci 1986; 9: 415-34.

22 Llorens-Cortes C, Schwartz JC. Enkephalinase activity in rat peripheral organs. Eur f Pharmacol 1981; 69: 113-6.

23 Pollard H, Moreau J, Ronco P, Verroust P, Schwartz JC. Immunoautoradiographic localisation of enkephalinase (EC 3.4.24.11) in rat gastrointestinal tract. Neuropeptides 1991; 19: 169-78,

24 McKnight AT, Corbett AD, Kosterlitz HW. Increase in potencies of opioid peptides after peptidase inhibition. Eurf Pharmacol 1983: 86: 393-402. 
25 Aoki K, Kajiwara M, Oka T. The role of bestatin-sensitive amino-peptidase, angiotensin converting enzyme and thiorphan-sensitive 'enkephalinase' in the potency of enkephalins in the guinea-pig ileum. Jpn f Pharmacol 1984; 36: 59-65.

26 Van Amsterdam JGC, Van Bunren KJH, Krichaart MJ, Zuiderveld OP, Tims RPJH. Effect of inhibitors of enkephalin degradation in the isolated guinea-pig ileum. Life Sci 1988; 43: 1529-36.

27 Marcais-Collado H, Uchida G, Costentin J, Schwartz JC, Lecomte JM. Naloxone-reversible antidiarrheal effects of enkephalinase inhibitors. Eur f Pharmacol 1987; 144: 12532.

28 Lecomte JM, Costentin J, Vlaiculescu A, Chaillet P, MarcaisCollado H, Llorens-Cortes C, et al. Pharmacological properties of acetorphan, a parenterally active 'enkephalinase' inhibitor. F Pharmacol Exp Ther 1986; 237: 937-44.

29 Chipkin RE, Berger JG, Billard W, Iorio LC, Chapman R, Barnett A. Pharmacology of SCH 34826, an orally active Barnett A. Pharmacology of SCH 34826 , an orally active enkephalinase inhibit

30 Bueno L, Fioramonti J. Enkephalins, other endogenous opioids and colonic motility in dog and man. Gastroentero Clin Biol 1987; 11: 69B-76B

31 Basilisco G, Bozzani A, Cambon G, Recchia M, Quatrini M Conte D, et al. Effect of loperamide and naloxone on mouthto-caecum transit time evaluated by lactulose hydrogen breath test. Gut 1985;26: 700-3.

32 Basilisco G, Camboni G, Bozzani A, Paravicini M, Bianchi PA. Oral naloxone antagonizes loperamide-induced delay of orocaecal transit. Dig Dis Sci 1987; 32: 829-32.

33 Kachel G, Ruppin H, Hagel J, Barina W, Meinhard T Domschke W. Human intestinal motor activity and transport: effects of a synthetic opiate. Gastroenterology transport: effects

34 Staniforth DH. Effects of drugs on orocaecal transit time assessed by the lactalose/breath hydrogen method. Eur $\mathcal{J}$ Clin Pharmacol 1987; 33: 55-8.

35 Pressman JH, Hofmann AF, Witztum KF, Gertler SL, Steinbach JH, Stokes K, et al. Limitations of indirect methods of estimating small bowel transit in man. Dig Dis Sci 1987; 32: 689-99.

36 O'Brien JD, Thompson DG, McIntyre A, Burnham WR Walker E. Effect of codeine and loperamide on upper intestinal transit and absorption in normal subjects and patients with posturogotomy diarrhoea. Gut 1988; 29: 312 8 .

37 Rubenstein E, Hofmann LM, Gourzis JT, Nolan RB. Comparison of a commercial bowel evacuant and castor oil with parison of a commercial bowel evacuant and castor oil with enemas 65 .

38 Gorbach SL. Infectious diarrhea. In: Sleisenger $\mathrm{MH}$, Fordtran JS, eds. Gastrointestinal diseases. 4th ed. Philadelphia: Saunders WB, 1989: 1191-232.

39 Ammon HV, Thomas PJ, Phillips S. Effects of oleic and ricinoleic acids on net jejunal water and electrolyte movement. F Clin Invest 1974; 53: 374-9.

40 Bright-Asare P, Binder HJ. Stimulation of colonic secretion of water and electrolytes by hydroxy fatty acids. Gastroenterology 1973; 64: 81-8.

41 Stewart JJ, Gaginella TS, Bass P. Actions of ricinoleic acid and structurally related fatty acids on the gastrointestinal tract. I. Effects on smooth muscle contractility in vitro. $\mathcal{F}$ Pharmacol Exp Ther 1975; 195: 347-54.

42 Gaginella TS, Stewart JJ, OIsen WA, Bass P. Actions of ricinoleic acid and structurally relatd fatty acids on the gastrointestinal tract. II. Effects on water and electrolyte absorption in vitro. $\mathcal{f}$ Pharmacol Exp Ther 1975; 195: 35561

43 Mihara S, North RA. Opioids increase potassium conductance in guinea pig submucous neurones by activating deltareceptors. Brf Pharmacol 1986; 88: 315-22.

44 Dobbins JW, Racusen L, Binder HJ. Effect of D-alanine methionine enkephalinamide on ion transport in rabbit ileum. F Clin Invest 1980; 66: 19-28.

45 Kachur JF, Miller RJ. Characterization of the opiate receptor in the guinea pig ileal mucosa. Eur $\mathcal{F}$ Pharmacol 1982; 81: $177-83$

46 Kachur JF, Miller RJ, Field M. Control of guinea pig intestinal electrolyte secretion by a delta-opiate receptor. Proc Natl Acad Sci USA 1982; 77: 2753-6.

47 Hautefeuille M, Brantl V, Dumontier AM, Desjeux JF. In vitro effects of b-casomorphins on ion transport in rabbit ileum. Am F Phvsiol 1986; 250 (Gastrointest Liver Physiol 13): G692-7.

48 Primi MP. Contrôle central neuropeptidergique et hormonal des sécrétions intestinales chez le chien. Institut National Polytechnique de Toulouse, France, 1986. Thèse de Doctorat.

49 Primi MP, Bueno L, Baumer Ph, Berard $\mathrm{H}$, Schwartz JC, Lecomte JM. Action anti-sécrétoire intestinale d'un inhibiteur de l'enképhalinase, l'acétorphan: démonstration in vivo chez le chien. Gastroenterol Clin Biol 1991; 15: A73.

50 Jivegard L, Pollard H, Moreau J, Schwartz JC, Thune A, Svanvik J. Naloxone-reversible inhibition of gall bladder Svanvik J. Naloxone-reversible inhibition of gall bladder
mucosal fluid secretion in experimental cholecystitis in the mucosal fluid secretion in experimental cholecystitis in the 77: 49-54.

51 Knisely JS, Beardsley PM, Aceto MD, Balster RL, Harris LS. Assessment of the abuse potential of acetorphan, an enkephalinase inhibitor. Drug Alcohol Depend 1989; 23: 14351 .

52 Bergmann JF, Chaussade S, Couturier D, Baumer $\mathrm{Ph}$, Schwartz JC, Lecomte JM. Effects of ocetorphan, an antidiarrheal enkephalinase inhibitor, on orocaecol and colonic transit times in healthy volunteers. Aliment Pharmacol Therap (in press)

53 Schuermans V, Lommel RV, Dom J, Brugmans J. Loperamide (R18553), a novel type of antidiarrheal agent. Placebo-controlled comparison of the constipating activity and safety of loperamide, diphenoxylate and codeine in normal volunteers. Arzneimittelforschung 1974; 24: 1653-7.

54 Johnson PC, Ericsson CD, Dupont HL, Moreau DR, Bitsura JAM, Wood LV. Comparison of loperamide with bismuth subsalicylate for the treatment of acute travelers diarrhea. 7AMA 1986; 255: 757-60. 